\title{
A Reply to Robert Gaucher
}

R. S. Ratner

In his article, ‘Organizing Inside: Prison Justice Day (August 10) ANonViolent Response to Penal Repression,' published in the recent issue of your journal (Vol. 3, Spring, 1991) Robert Gaucher makes an ill-considered attack on Canadian social scientists and on my own views regarding prisoners/political struggles. In the first page of his article, he writes that: The political consciousness and struggles of Canadian prisoners has been either denied or ignored by Canadian criminologists and social scientists.'

I know of several Canadian academics who take up this issue quite seriously in their work; so Gaucher's implied condemnation is unwarranted, and apparently designed to highlight his own contribution, which, it should be noted, is being offered largely in his capacity as one of those allegedly obtuse Canadian academics.

In a footnote (n. 1) supposedly qualifying his untrue assertion, Gaucher writes the following:

See for example R.S. Ratner and B. Cartwright (1990). Their argument denigrates prisoner politics and in doing so represents many of the problems associated with a variety of academic criminology and social science discourses which deny political credibility to prisoners' struggles.

This is a complete misinterpretation of our article, but the reader of Gaucher's piece would not be able to check out his understanding of it very easily, since the reference to the article is omitted in the items listed under 'References.' If any of the readers of Gaucher's article do want to follow this up, the full reference for the article which he so blithely caricatures is, Politicized Prisoners: From Class Warriors to Faded Rhetoric,' R.S. Ratner and Barry Cartwright. 1990. Journal of Human Justice, 2 (1): 75-92.

The point of our article was to indicate the continuing potential for prisoner politicization, to identify some of the barriers to such politicization, and to explain the relative quiescence of prisoner political protest in Canada as compared with the U.S. The article also examined current efforts by Canadian correctional administrators to re-individualize prisoner protest in order to prevent collective action by prisoners. The article ends on the following note:

The important lesson that can be drawn from the past thirty years of prison protest is that if prisoner movements are to succeed, they cannot be separate and parochial, but must be joined to other groups and social movements. 
Prisoner groups must be projected back into society rather than allowed to remain isolated and distinct, as, perhaps, the authorities mean them to be. Non-prisoners must know that 'prisoners' and 'prisons' are not in their interests, and radical criminologists must not retreat from the task of helping all of these groups to discover their common unifying purpose (p. 87).

How any reader can conclude that this is a 'denigration' of prisoner politics is beyond me. On the contrary, the main point of the article was to clarify how prisoner protest might be more effective; that it needs to be is something that Gaucher surely would not deny. Our article was based on ten years of cumulative research involving interviews and discussions with incarcerated and released prisoners, prison activists, prisoner education groups, correctional officials, and an informative conversation with Gaucher himself, who, at least at the time, seemed to accept our argument and provided supportive anecdotes. I also studied a variety of penal press publications covering a fifteen year span, then passing them on to Gaucher to assist him with his own work. So I am mystified that he would take issue with our argument, and misrepresent it as he has done.

More importantly, there is something very disturbing and saddening about this, because I think Gaucher's hyperbolic criticism cements a Them-Us polarization, in which Canadian criminologists and social scientists are the objectionable 'Them.' I grant that there are some people who do camp themselves in this way, but I have tried to oppose this separation in my own academic practice, and I had the gratifying impression that the line was becoming blurred between Them and Us, and might continue to grow more indistinct. I guess I was wrong, if Gaucher's response to our article is any indication.

I do believe that, in our article, we did our utmost to report the truth, as revealed to us by our informants and our research. Although I recognize that 'truth' is a problematic concept, I do not believe that all truths can be reduced to however any one group chooses to see the world. It is especially troubling when truth gets blurred for utterly prejudicial reasons. 